\title{
Power-based Resistance Training Reduced Serum Oxidized Low-Density Lipoprotein in Athletes
}

\author{
Yunsuk Koh ${ }^{*}$, Jos hua Miller
}

Department of Health and Kinesiology, Lamar University, Beaumont, TX 77710, USA

\begin{abstract}
Power-based resistance training (PRT) allows athletes to improve athletic performance by enhancing both strength and power simultaneously. However, it is unclear whether athletes who participate in PRT can positively alter serum lipid and lipoprotein parameters. Thus, the current study investigated the effects of 6-weeks of PRT on serum lipid and lipoprotein parameters in male and female collegiate athletes. Twenty one collegiate athletes ( 12 female soccer players and 9 male football players) participated in PRT (4 days/week) for 6 weeks. The PRT program was composed of a variety of Olympic-style and traditional weightlifting movements along with plyometrics. Overnight fasting blood samples were collected before and after 6-weeks of power-based resistance training to analyze serum lipid and lipoprotein parameters including TG, TC, VLDL-C, LDL-C, HDL-C, Lp(a), and ox-LDL. All serum lipid and lipoprotein parameters remained unchanged, except ox-LDL which significantly $(\mathrm{p}=0.036)$ decreased by $3.81 \%$ or $1.87 \mathrm{U} \cdot \mathrm{L}^{-1}$ (from $49.05 \pm 9.17$ to $47.18 \pm$ $9.78 \mathrm{U} \cdot \mathrm{L}^{-1}$ ) following 6 weeks of power-based resistance training. The 6-weeks of PRT, designed to improve strength and power, can provide card ioprotective health benefits for male and female collegiate athletes by lowering ox-LDL.
\end{abstract}

Keywords Blood Lipids, Card ioprotective Benefits, Weight Training, Complex Training

\section{Introduction}

Cardiovascular disease (CVD) has been recognized as a major leading cause of death in America for more than 10 decades, and approximately 2,200 Americans die of CVD everyday[1]. Abnormal blood lipids and lipoproteins known as dyslipidemia are considered one of the primary risk factors for development of CVD and characterized by elevated total cholesterol (TC), triglycerides (TG), or low-density lipoprotein cholesterol (LDL-C) and lowered high-density lipoprotein cholesterol (HDL-C)[2]. In addition, a strong body of evidence suggests that elevated serum oxidized LDL (ox-LDL) is a key factor that accelerates the incidence of CVD by promoting the atherosclerotic progression of plaque[3].

Physical activity, as a non-pharmacological treatment, is often recommended for sedentary individuals or patients with CVD to positively modify blood lipids and lipoproteins [2]. According to the meta-analysis, aerobic exercise can decrease TC (2.0\%), LDL-C (3\%), and TG $(5.0$ $-9.0 \%)$ and increase HDL-C $(2.0-3.0 \%)$ in adults[4,5]. However,the effects of anaerobic exercise such as resistance training on blood lipids and lipoproteins are equivocal[6-8]. One meta-analys is has recently reported that resistance

* Corresponding author:

ykoh@lamar.edu (Yunsuk Koh)

Published online at http://journal.sapub.org/sports

Copyright (C) 2012 Scientific \& Academic Publishing. All Rights Reserved exercise may decrease TC (2.7\%), LDL-C (4.6\%), and TG (6.4\%), but not HDL-C, in adults [6], whereas another review study has reported no strong evidence of beneficial effects of resistance exercise on modification of blood lipids and lipoproteins[7]. Moreover, only a few studies have previously examined the responses of ox-LDL to exercise training, and the results are inconsistent[9-12].

American Heart Association and American College of Sport Medicine recommend moderate intensity resistance exercise to be part of the main exercise program for sedentary or untrained individuals because it helps prevent CVD and promote muscular strength and endurance, functional capacity, health, and fitness[7,13,14]. Unlike sedentary or untrained individuals whose main goal of resistance training is to improve their health or fitness, most trained athletes usually participate in relatively higher intensity resistance exercise to promote athletic performance rather than health or fitness. Power-based resistance training (PRT) is often recommended by many strength and conditioning professionals because it allows athletes to enhance athletic performance by gaining both strength and power simultaneously[15]. The recommended form of PRT is a co mb ination of a variety of Oly mpic-style and traditional weightlifting movements and plyometrics[16]. Several studies have previously reported the positive effects of PRT on improvement in strength and performance in athletes [17-20]. However, it is unclear whether athletes participating in high intensity resistance training such as PRT can obtain cardioprotective health benefits as well. To date, no study 
has examined the effects of PRT on serum lipids and lipoproteins including ox-LDL in athletes. Thus, the current study investigated whether 6-weeks of PRT can provide male and female collegiate athletes with cardioprotective health benefits.

\section{Method}

\subsection{Participants}

Twenty one collegiate athletes (12 female soccer players and 9 ma le football players), between 18 and 23 years of age, participated in the study during the off-season. All participants were physically active (defined as a regular physicalactiv ity performed mo re than 4 days a week), free of any self-reported injury and cardiovascular or metabolic diseases, and not taking any medications known to alter blood lipids and lipoproteins. The participants provided written informed consent and the medical history forms prior to performing any study protocols. All study procedures were reviewed and approved by the Institutional Review Board. The participants were encouraged to maintain a normal dietary regimen, and refrained from any types of strenuous exercises other than PRT throughout the study period. In addition, no competitive football or soccer games were scheduled during the study period.

\subsection{Procedures}

Table 1. A Specific Exercise Protocol for PRT

\begin{tabular}{|c|c|c|c|c|}
\hline & $\begin{array}{c}\text { Monday } \\
\text { (Lower Body) }\end{array}$ & $\begin{array}{c}\text { Tuesday } \\
\text { (Upper Body) }\end{array}$ & $\begin{array}{l}\text { Thursday } \\
\text { (Lower Body) }\end{array}$ & $\begin{array}{c}\text { Friday } \\
\text { (Upper Body) }\end{array}$ \\
\hline Warmup & \multicolumn{4}{|c|}{$\begin{array}{c}\text { Ankle Disc, Rotator Cuff Series, Rotex or Slide board, Hurdle Mobility Routine, Speed Ladder Routine, Jump Rope } \\
\text { Routine, Neck Machine, Weighted or Non-weight Abdominal Circuit }\end{array}$} \\
\hline $\begin{array}{l}\text { Olympic-style } \\
\text { Weightlifting }\end{array}$ & $\begin{array}{c}\text { Clean, } \\
\text { Snatch Pull, } \\
\text { Hang Snatch }\end{array}$ & Split Jerk & $\begin{array}{l}\text { Snatch, } \\
\text { Clean Pull, } \\
\text { Hang Clean }\end{array}$ & Power Jerk \\
\hline $\begin{array}{l}\text { Traditional } \\
\text { Weightlift ing }\end{array}$ & $\begin{array}{l}\text { Clean Grip RDL, } \\
\text { Back Squat, } \\
\text { Snatch Grip Lunges }\end{array}$ & $\begin{array}{c}\text { InclinePress, } \\
\text { Bar Rows, } \\
\text { Single Arm Dumbell Bench, } \\
\text { Pullups/Pulldowns }\end{array}$ & $\begin{array}{l}\text { Single Leg RDL, } \\
\text { Front Squat, } \\
\text { Side Lunges }\end{array}$ & $\begin{array}{c}\text { Bench Press, } \\
\text { Dumbell Rows, } \\
\text { Standing Military Press, } \\
\text { Alternat ing Dumbell } \\
\text { Incline }\end{array}$ \\
\hline $\begin{array}{l}\text { Plyometrics } \\
\text { (sets X reps) }\end{array}$ & $\begin{array}{c}\text { Platform Plyos (lateral } \\
\text { jumps-3X5, each way), } \\
\text { Bear Squat Jumps (3X6) }\end{array}$ & $\begin{array}{c}\text { Hurdle Hops, } \\
\text { Power Bears (3X5) }\end{array}$ & $\begin{array}{c}\text { Incline Medicine Ball } \\
\text { Press (3X8), } \\
\text { Medicine Ball Slams (3X9) }\end{array}$ & $\begin{array}{c}\text { Medicine Ball Bench Press } \\
\text { (3X8), } \\
\text { Single Leg } \\
\text { Overheadmedicine Ball } \\
\text { Toss (3X6, each leg) }\end{array}$ \\
\hline $\begin{array}{l}\text { Supplemental } \\
\text { Movements } \\
\text { (sets X reps) }\end{array}$ & $\begin{array}{l}\text { Swiss Ball Hamstring Work } \\
\text { (3X12), } \\
\text { Single Leg Goodmornings } \\
\text { (2X8, each leg) }\end{array}$ & $\begin{array}{c}\text { Alternat ing Dumbell } \\
\text { Military Press (3X8, each } \\
\text { arm), } \\
\text { Dumbell Reverse Flys } \\
(3 \mathrm{X} 10)\end{array}$ & Gluteham (3X8) & $\begin{array}{l}\text { Bar Sit Ups }(3 \mathrm{X} 12), \\
\text { Inverted Rows }(3 \mathrm{X} 10) \text {, } \\
\text { Hanging Abs (3X25) }\end{array}$ \\
\hline Cooldown & $\begin{array}{c}\text { PNF } \\
\text { (lower body) }\end{array}$ & $\begin{array}{c}\text { PNF } \\
\text { (upper body) }\end{array}$ & $\begin{array}{c}\text { PNF } \\
\text { (lower body) }\end{array}$ & $\begin{array}{c}\text { PNF } \\
\text { (upper body) }\end{array}$ \\
\hline
\end{tabular}

The participants were tested for one-repetition maximum (1-RM) in clean, incline press, and Olymp ic-style back squat (angle of knee $<90^{\circ}$ ) on a separate day to determine the lower and upper body strength. The initial weight for the 1-RM test was determined by the participant's training history. Once the participants successfully lifted the first weight, additional resistance $(2.5-5.0 \mathrm{~kg})$ was added until the participants were not able to success fully comp lete a lift. The participants rested for 3 minutes between each 1-RM attempt to recover from the previous attempt, and the last success ful lift was recorded as 1-RM.

The 1-RM for other upperand lower body movements was estimated by pre-determined 1-RM of clean, incline press, or squat. For instance, the 1-RM for the following Olympic style weightlifting movements was estimated by the clean $1-\mathrm{RM}$; snatch $-60 \%$ of clean $1-\mathrm{RM}$, clean pull $-120 \%$ of clean 1-RM, hand clean and Romanian deadlift (RDL)-90\% of clean 1-RM, jerk variations $-90 \%$ of clean $1-\mathrm{RM}$, snatch pull $-72 \%$ of clean 1-RM (equivalent to $120 \%$ of snatch $1-\mathrm{RM}$ ), and hang snatch $-54 \%$ of clean 1-RM (equivalent to $90 \%$ of snatch 1-RM). The 1-RM for the traditional horizontal bench press was estimated to be $120 \%$ of incline press 1-RM. The Olympic-style back squat 1-RM was used to estimate the $1-\mathrm{RM}$ for the front squat ( $80 \%$ of squat $1-\mathrm{RM})$ and lunge variations ( $25 \%$ of squat $1-\mathrm{RM})$.

\subsection{Power-based Resistance Training (PRT) Program}


The PRT program consisted of a combination of various Olympic-style and traditional weightlifting movements along with plyometrics as shown in Table 1 . The participants performed PRT for 4 days per week (Monday, Tuesday, Thursday, and Friday) for 6 weeks. After performing a series of selected warm-up activities for 15 minutes, the participants performed each PRT session around 60 minutes. In the current study, following weekly undulating periodization was used; week $1-70 \%$ 1-RM, week $2-80 \%$ 1-RM, week $3-75 \%$ 1-RM, week $4-90 \% 1$-RM, week 5 $80 \% 1-\mathrm{RM}$, and week $6-95 \% 1-\mathrm{RM}$. For a cool-down, a variety of proprioceptive neuromuscular facilitation stretches targeting upper (chest, rotator cuff,deltoids, and upper back) or lower (hamstrings, hips/glutes, lower back, and quadriceps) body muscle groups were performed for 10 minutes after each workout. All PRT sessions were supervised and led by a certified strength and conditioning professional to ensure maximu m compliance.

\subsection{Analyses of TC, TG, and Ox-LDL}

The participants reported to the laboratory for blood draw between 07:00 and 08:00 AM after 10-12 hours of overnight fasting. Blood samples were collected at pre(week 0) and post-PRT (week 7). After 15 minutes of resting in a chair, venous blood was drawn fro $m$ the antecubital vein. Immediately after blood draw, blood samples remained at room te mperature for 20 minutes to be clotted, and then were centrifuged at $1,800 \mathrm{~g}$ for 15 minutes to separate serum. Serum samples were then immediately frozen at $-80^{\circ} \mathrm{C}$ for the further analysis of serum lipid and lipoprotein parameters.

Serum samples in duplicate were assayed for TC (Kit\# 85430, Cliniqa, San Marcos, CA) and TG (Kit\# 85460, Cliniqa, San Marcos, CA) by an enzymatic colorimetric method, and ox-LDL was analyzed by an enzyme-linked immumosorbent assay (Cat\# 10-1143-01, Mercodia, Uppsala, Sweden). Optical density was measured by the Spectra Max Plus 384 microplate spectrophotometer (Molecular Devices, Sunnyvale, CA). Each assay was performed as instructed by the manufacture's assay procedure. To minimize inter- and intra-assay variability, all serum samp les for each assay were analy zed at one time in a single plate.

\subsection{Analys es of Serum Lipoprotein-cholesterol}

Serum lipoprotein-choles terol including VLDL-C, LDL-C, HDL-C, and Lp(a) were analyzed by electrophores is (Cat. \# 3438 SPIFE Vis Cholesterol, Helena Laboratory, Beaumont, TX) using the SPIFE 3000 electrophores is system (Helena Laboratory, Beaumont, TX). The lipoprote in-cholesterol analysis was performed as instructed by the manufacture's assay procedures, using a commercially available control (Cat. \# 3218, Helena Laboratory, Beaumont, TX). In brief, $80 \mu \mathrm{L}$ of serum samples, in duplicate, were applied to an agarose gel followed by 20 minutes of electrophoresis at $16{ }^{\circ} \mathrm{C}$ with 400 volts. After applying a staining regent (Cat. \# 3438, Helena Laboratory, Beaumont, TX), additional electrophoresis was performed at $30{ }^{\circ} \mathrm{C}$ for 15 minutes. The gel was washed and dried at $70{ }^{\circ} \mathrm{C}$ for 20 minutes, and the density of stained lipoprotein-cholesterol bands were measured in a scanning densitometer (Epson Perfection V 700, Long beach, CA) using Quick Scan 2000 software (Helena Laboratory, Beaumont, TX). To minimize inter- and intra-assay variability, all serum samples were analyzed at one time in a single gel.

\subsection{Statistical Analyses}

The sample size was calculated by $\mathrm{G}^{*}$ Power 3.1 .0 software[21], given an alpha level at 0.05 , an effect size of 0.40 , and power at 0.80 . The appropriate sample size was estimated to be 16 participants for the current study design. All statistical analyses were performed using the IBM Statistical Package for the Social Sciences 19.0 (IBM SPSS, Armonk, NY) and reported as mean \pm standard deviation (SD) unless stated otherwise. The Shapiro-Wilk test was employed to test the normality of data, and indicated that data were normally distributed. An independent-Samples T test was used to examine the baseline differences in anthropometrical and physiological variables between males and females. A 2 (group; males and females) X 2 (time; preand post-PRT) repeated measures analysis of variance (ANOVA) was employed to determine the significant changes in serum lipid and lipoprotein parameters. If the main or interaction effects were significant, Bonferroni pairwise comparisons were conducted to examine the significant mean differences. A $p$-value $<0.05$ was considered to be statistically significant.

\section{Results}

The demographic and physiological characteristics of participants at baseline are presented in Table 2. No serum lip id or lipoprotein parameters at baseline were significantly different between groups, whereas height (males: $180.90 \pm$ 8.28 vs. females: $167.11 \pm 6.44 \mathrm{~cm}$ ) and weight (males: $102.58 \pm 18.30 \mathrm{vs}$. females: $65.00 \pm 8.21 \mathrm{~kg}$ ) were significantly different $(p=0.001)$. However, these anthropometric variables were not significantly altered within each group following 6-weeks of PRT.

The main effects for group and time on changes in serum lipids and lipoproteins are presented in Table 3 and 4, respectively. There were no significant main effects for group and time or the group $\mathrm{X}$ time interaction for any of the serum lip id or lipoprotein parameters, except ox-LDL which had a significant main effect for time, indicating that ox-LDL significantly $(p=0.036)$ decreased by $1.87 \mathrm{U} \cdot \mathrm{L}^{-1}$ or $3.81 \%$ (from $49.05 \pm 9.17$ to $47.18 \pm 9.78 \mathrm{U} \cdot \mathrm{L}^{-1}$ ) following 6 weeks of PRT (Table 4). 
Table 2. The Demographic and Physiological Characteristics of P articipants at Baseline

\begin{tabular}{|c|c|c|c|c|}
\hline & $\begin{array}{l}\text { Females } \\
(\mathrm{n}=12)\end{array}$ & $\begin{array}{l}\text { Males } \\
(\mathrm{n}=9)\end{array}$ & $\begin{array}{l}\text { Mean } \\
(\mathrm{n}=21)\end{array}$ & $p$ \\
\hline Age (yr) & $19.00 \pm 0.65$ & $21.00 \pm 1.13$ & $20.00 \pm 1.06$ & 0.130 \\
\hline Height $(\mathrm{cm})$ & $167.11 \pm 6.44$ & $180.90 \pm 8.28^{*}$ & $173.02 \pm 9.96$ & 0.001 \\
\hline Weight $(\mathrm{kg})$ & $65.00 \pm 8.21$ & $102.58 \pm 18.30^{*}$ & $81.10 \pm 23.11$ & 0.001 \\
\hline $\mathrm{TG}\left(\mathrm{mmol} \cdot \mathrm{L}^{-1}\right)$ & $0.66 \pm 0.21$ & $0.70 \pm 0.25$ & $0.68 \pm 0.22$ & 0.720 \\
\hline $\mathrm{TC}\left(\mathrm{mmol} \cdot \mathrm{L}^{-1}\right)$ & $4.07 \pm 0.49$ & $4.67 \pm 0.67$ & $4.33 \pm 0.64$ & 0.170 \\
\hline LDL-C $\left(\mathrm{mmol} \cdot \mathrm{L}^{-1}\right)$ & $2.53 \pm 0.53$ & $3.25 \pm 0.62$ & $2.84 \pm 0.67$ & 0.082 \\
\hline $\operatorname{VLDL}-\mathrm{C}\left(\mathrm{mmol} \cdot \mathrm{L}^{-1}\right)$ & $0.06 \pm 0.14$ & $0.09 \pm 0.21$ & $0.08 \pm 0.17$ & 0.727 \\
\hline $\mathrm{Lp}(\mathrm{a})\left(\mathrm{mmol} \cdot \mathrm{L}^{-1}\right)$ & $0.04 \pm 0.06$ & $0.01 \pm 0.01$ & $0.02 \pm 0.04$ & 0.115 \\
\hline HDL-C $\left(\mathrm{mmol} \cdot \mathrm{L}^{-1}\right)$ & $1.44 \pm 0.28$ & $1.33 \pm 0.43$ & $1.39 \pm 0.39$ & 0.519 \\
\hline Ox-LDL $\left(\mathrm{U} \cdot \mathrm{L}^{-1}\right)$ & $48.38 \pm 8.55$ & $49.95 \pm 10.40$ & $49.05 \pm 9.17$ & 0.716 \\
\hline
\end{tabular}

Note. Values $=$ mean $\pm \mathrm{SD} ; \mathrm{TG}=$ triglycerides; $\mathrm{TC}=$ total cholesterol; LDL-C $=$ low-density lipoprotein-cholesterol; VLDL-C=very low-density lipoprotein cholesterol; $\mathrm{Lp}(\mathrm{a})=$ lipoprotein $(\mathrm{a}) ; \mathrm{HDL}-\mathrm{C}=$ high-density lipoprotein - cholesterol; Ox-LDL = oxidized LDL. ${ }^{*} p=0.001$, significantly different from fem ales

Table 3. Main Effects for Group on Changes in Serum Lipid and Lipoprotein Parameters

\begin{tabular}{|c|c|c|c|c|}
\hline & \multicolumn{2}{|c|}{ Females $(n=12)$} & \multicolumn{2}{|c|}{ Males $(n=9)$} \\
\hline & Pre-PRT & Post-PRT & Pre-PRT & Post-PRT \\
\hline $\mathrm{TG}\left(\mathrm{mmol} \cdot \mathrm{L}^{-1}\right)$ & $0.66 \pm 0.21$ & $0.66 \pm 0.22$ & $0.70 \pm 0.25$ & $0.67 \pm 0.25$ \\
\hline $\mathrm{TC}\left(\mathrm{mmol} \cdot \mathrm{L}^{-1}\right)$ & $4.07 \pm 0.49$ & $4.03 \pm 0.49$ & $4.67 \pm 0.67$ & $4.55 \pm 0.84$ \\
\hline LDL-C $\left(\mathrm{mmol} \cdot \mathrm{L}^{-1}\right)$ & $2.53 \pm 0.53$ & $2.51 \pm 0.52$ & $3.25 \pm 0.62$ & $3.06 \pm 0.71$ \\
\hline $\operatorname{VLDL}-\mathrm{C}\left(\mathrm{mmol} \cdot \mathrm{L}^{-1}\right)$ & $0.06 \pm 0.14$ & $0.09 \pm 0.16$ & $0.09 \pm 0.21$ & $0.16 \pm 0.24$ \\
\hline $\mathrm{Lp}(\mathrm{a})\left(\mathrm{mmol} \cdot \mathrm{L}^{-1}\right)$ & $0.04 \pm 0.06$ & $0.04 \pm 0.07$ & $0.01 \pm 0.01$ & $0.01 \pm 0.01$ \\
\hline HDL-C $\left(\mathrm{mmol}^{-1} \mathrm{~L}^{-1}\right)$ & $1.44 \pm 0.28$ & $1.38 \pm 0.28$ & $1.33 \pm 0.43$ & $1.32 \pm 0.25$ \\
\hline Ox-LDL $\left(U \cdot L^{-1}\right)$ & $48.38 \pm 8.55$ & $47.80 \pm 8.82$ & $49.95 \pm 10.40$ & $46.37 \pm 11.44$ \\
\hline
\end{tabular}

Note. Values = mean $\pm \mathrm{SD} ; \mathrm{PRT}=$ power-based resistance training; $\mathrm{TG}=$ triglycerides; $\mathrm{TC}=$ total cholesterol; LDL-C=low-density lipoprotein-cholesterol; VLDL-C = very low-density lipoprotein-cholesterol; Lp(a) = lipoprotein(a); HDL-C = high-density lipoprotein-cholesterol; Ox-LDL = oxidized LDL

Table 4. Main Effects for Time on Changes in Serum Lipid and Lipoprotein Parameters

\begin{tabular}{ccc}
\hline & Pre-PRT & Post-PRT \\
\hline T G $\left(\mathrm{mmol} \cdot \mathrm{L}^{-1}\right)$ & $0.68 \pm 0.22$ & $0.66 \pm 0.23$ \\
TC $\left(\mathrm{mmol} \cdot \mathrm{L}^{-1}\right)$ & $4.33 \pm 0.64$ & $4.26 \pm 0.69$ \\
LDL-C $\left(\mathrm{mmol} \cdot \mathrm{L}^{-1}\right)$ & $2.84 \pm 0.67$ & $2.75 \pm 0.66$ \\
VLDL-C $\left(\mathrm{mmol} \cdot \mathrm{L}^{-1}\right)$ & $0.08 \pm 0.17$ & $0.12 \pm 0.20$ \\
Lp(a) $\left(\mathrm{mmol} \cdot \mathrm{L}^{-1}\right)$ & $0.02 \pm 0.04$ & $0.02 \pm 0.05$ \\
HDL-C $\left(\mathrm{mmol} \cdot \mathrm{L}^{-1}\right)$ & $1.39 \pm 0.39$ & $1.36 \pm 0.27$ \\
Ox-LDL $\left(\mathrm{U} \cdot \mathrm{L}^{-1}\right)$ & $49.05 \pm 9.17$ & $47.18 \pm 9.78^{*}$ \\
\hline
\end{tabular}

Note. Values $=$ mean $\pm \mathrm{SD} ; \mathrm{PRT}=$ power-based resistance training; $\mathrm{TG}=$ triglycerides; $\mathrm{TC}=$ total cholesterol; LDL-C $=$ low-density lipoprotein-cholesterol; VLDL-C = very low-density lipoprotein-cholesterol; Lp(a) = lipoprotein (a); HDL-C = high-density lipoprotein-cholesterol; Ox-LDL = oxidized LDL. ${ }^{*} \mathrm{p}=$ 0.036, significantly different from Pre-PRT

\section{Discussion}

This study was the first to examine the effects of PRT on cardioprotective health benefits in male and female collegiate athletes. Although we do not discuss about the results of PRT-induced strength gain in this paper, our unpublished data have shown that the participants significantly improved upper and lower body strength up to $15.0 \%$ fo llowing 6-weeks of PRT.

In the current study, no serum lipid or lipoprotein parameters, except ox-LDL, significantly changed following 6-weeks of PRT. This result was consistent with other previous studies reporting that resistant training lasting for up to 16 weeks improved upper and lower body strength, but did not significantly alter serum lipids and lipoproteins in a variety of subject groups including untrained men[22] and women[23], patients with type 2 diabetes[24], obese individuals with CVD risk factors[25], or postmenopausal women[26]. Some studies that examined the effects of different intensities or repetitions of resistance training on serum lipids and lipoproteins in men or women have also found no beneficial effects of resistance training[27-29]. Moreover, several studies have reported an exerc ise-induced increase in $\mathrm{Lp}$ (a) or TG following 24 weeks of low-intensity resistance training or a single session of circuit-resistance exercise[27,29].

In contrast, other studies have reported a favorable effect of resistance training on serum lipids and lipoproteins including a decrease in TC, LDL-C, and TG and/or an increase in HDL-C[30-32]. For instance, sedentary wo men who participated in 3-days of non-consecutive resistant training (85\% 1-RM) for 14 weeks decreased TC, LDL-C, and the TC to HDL-C ratio, increased HDL-C, but did not change TG[32]. Similar results have also been observed in obese women who participated in 9-weeks of resistance training; however, the TG concentration in obese women significantly increased following resistance training[30]. Another study examining the effects of high intensity resistance training ( 3 sets of 8 repetitions) has reported an increase in HDL-C and a decrease in TG without changing 
body weight or diet in healthy, active postmenopausal wo men[31].

Based on the previous studies, it is difficult to conclude whether resistance training can positively alter serum lipids and lipoproteins. One of the recent review papers has suggested that if resistance training could positively influence on serum lipids and lipoproteins, the primary outcome would be a reduction of LDL-C for both men and wo men, with a reduction of TC being a secondary outcome for only wo men[33]. One of the possible explanations for the lack of significant changes in serum lipids and lipoproteins in the current study may be our participants' good training background. All participants in the current study were physically active (performed physical activity more than 4 days per week) and trained for many years. Most studies that have reported a significant change in serum lipids and lipoproteins investigated in sedentary or untrained individuals. Additionally, the initial serum lipid and lipoprotein parameters at baseline for our participants were within the normal range.

Only a few studies have previously examined the effects of exercise training on ox-LDL metabolis $\mathrm{m}$, and most of the studies employed aerobic exercise training as an intervention [9-12]. Furthermore, the results of these studies are inconsistent. The concentration of ox-LDL decreased after acute prolonged or moderate intensity aerobic exercise training in healthy[10] and obese[9] individuals. However, individuals with some types of metabolic diseases such as untreated mild hypertension with atherogenic lipid profiles[11] or type II diabetes[12] increased ox-LDL following acute resistance exercise. The authors have speculated that one of the possible explanations for an increase in ox-LDL following resistance training observed in patients with metabolic diseases could be a compensatory mechanis $m$ to preventing free radical tissue damage[12].

In the current study, the serum ox-LDL concentration was significantly reduced by $3.81 \%$ (or $1.87 \mathrm{U} \cdot \mathrm{L}^{-1}$ ) following 6-weeks of PRT. Similar to the current study, only serum ox-LDL, but no other lipid or lipoprotein parameters, significantly decreased after high-intensity strength training in obese adults [9] that performed lower body strength training for 12 weeks at $90 \%$ of 1-RM along with several abdominal and back exercises consisting of 3 series of 30 repetitions[9]. According to several studies that examined the relationship between physical tra ining status and ox-LDL levels in young female[34] and veteran endurance male [35] athletes, the trained athletes tend to have lower ox-LDL than their untrained counterparts, suggesting that atherogenic risk can be favorably influenced by participation in exercise training and affected as early as in adolescents [34].

\section{Conclusions}

Our study suggests that 6-weeks of PRT consisting of a combination of Olympic-style and traditional weightlifting movements and plyometrics can provide colleg iate athletes with cardioprotective health benefits by lowering ox-LDL. Although the exact mechanis $m$ by which exercise decreases ox-LDL has not been fully understood, high-intensity resistance training such as PRT may prevent risk for atherosclerosis and CVD in individuals without atherogenic risk factors.

\section{REFERENCES}

[1] Roger V. L., Go A. S., Lloyd-Jones D. M., Benjamin E. J., Berry J. D., Borden W. B., Bravata D. M., Dai S., Ford E. S., Fox C. S., Fullerton H. J., Gillespie C., Hailpern S. M., Heit J. A., Howard V. J., Kissela B. M., Kittner S. J., Lackland D. T., Lichtman J. H., Lisabeth L. D., Makuc D. M., Marcus G. M., Marelli A., Matchar D. B., Moy C. S., Mozaffarian D., Mussolino M. E., Nichol G., Paynter N. P., Soliman E. Z., Sorlie P. D., Sotoodehnia N., Turan T. N., Virani S. S., Wong N. D., Woo D., Turner M. B., American Heart Association Statistics Committee, Stroke Statistics Subcommittee, "Executive Summary: Heart Disease and Stroke Statistics--2012 Update: A Report from the American Heart Association", Circulation, vol. 125, no. 1, pp. 188-197, 2012.

[2] NCEP, "Third Rep ort of the National Cholesterol Education Program (Ncep) Expert Panel on Detection, Evaluation, and Treatment of High Blood Cholesterol in Adults (Adult Treatment Panel Iii) Final Report", Circulation, vol. 106, no. 25, pp. 3143-3421, 2002.

[3] Shimada K., Mokuno H., Matsunaga E., Miyazaki T., Sumiy oshi K., Miy auchi K.,Daida H., "Circulating Oxidized Low-Density Lipoprotein Is an Independent Predictor for Cardiac Event in Patients with Coronary Artery Disease", Atherosclerosis, vol. 174, no. 2, pp. 343-347, 2004.

[4] Kelley G. A.,Kelley K. S., "Aerobic Exercise and Lipids and Lipoproteins in Men: A Meta-Analysis of Randomized Controlled Trials", J Mens Health Gend, vol. 3, no. 1, pp. 61-70, 2006.

[5] Kelley G. A., Kelley K. S.,Tran Z. V., "Aerobic Exercise and Lipids and Lipoproteins in Women: A Meta-Analysis of Randomized Controlled Trials", J Womens Health (Larchmt), vol. 13, no. 10, pp. 1148-1164, 2004.

[6] Kelley G. A.,Kelley K. S., "Impact of Progressive Resistance Training on Lipids and Lipoproteins in Adults: A Meta-Analy sis of Randomized Controlled Trials", Prev Med, vol. 48, no. 1, pp. 9-19, 2009.

[7] Williams M. A., Haskell W. L., Ades P. A., Amsterdam E. A., Bittner V., Franklin B. A., Gulanick M., Laing S. T., Stewart K. J., American Heart Association Council on Clinical Cardiology, American Heart Association Council on Nutrition Physical Activity,Metabolism, "Resistance Exercise in Individuals with and without Cardiovascular Disease: 2007 Update: A Scientific Statement from the American Heart Association Council on Clinical Cardiology and Council on Nutrition, Physical Activity, and Metabolism", Circulation, vol. 116, no. 5, pp. 572-584, 2007.

[8] Braith R. W.,Stewart K. J., "Resistance Exercise Training: Its Role in the Prevention of Cardiovascular Disease", 
Circulation, vol. 113, no. 22, pp. 2642-2650, 2006.

[9] Schjerve I. E., Tyldum G. A., Tjonna A. E., Stolen T., Loennechen J. P., Hansen H. E., Haram P. M., Heinrich G., Bye A., Najjar S. M., Smith G. L., Slordahl S. A., Kemi O. J.,Wisloff U., "Both Aerobic Endurance and Strength Training Programmes Improve Cardiovascular Health in Obese Adults", Clin Sci (Lond), vol. 115, no. 9, pp. 283-293, 2008.

[10] Vuorimaa T., Ahotupa M., Irjala K.,Vasankari T., "Acute Prolonged Exercise Reduces Moderately Oxidized Ldl in Healthy Men", Int J Sports Med, vol. 26, no. 6, pp. 420-425, 2005.

[11] Caparevic Z., Kostic N., Celic V., Cosic Z., Marina D., Ilic S.,Pencic B., "Effects of Acute Exercise on Atherogenic Lipids in Untreated Mild Hypertensive Patients", Vojnosanit Pregl, vol. 66, no. 4, pp. 313-318, 2009.

[12] Kostic N., Caparevic Z., Marina D., Ilic S., Radojkovic J., Cosic Z.,Bakic-Celic V., "Clinical Evaluation of Oxidative Stress in Patients with Diabetes Mellitus Type Ii -- Impact of Acute Exercise", Vojnosanit Pregl, vol. 66, no. 6, pp. 459-464, 2009.

[13] Pearson T. A., Blair S. N., Daniels S. R., Eckel R. H., Fair J. M., Fortmann S. P., Franklin B. A., Goldstein L. B., Greenland P., Grundy S. M., Hong Y., Miller N. H., Lauer R. M., Ockene I. S., Sacco R. L., Sallis J. F., Jr., Smith S. C., Jr., Stone N. J.,Taubert K. A., "Aha Guidelines for Primary Prevention of Cardiovascular Disease and Stroke: 2002 Update: Consensus Panel Guide to Comprehensive Risk Reduction for Adult Patients without Coronary or Other Atherosclerotic Vascular Diseases. American Heart Association Science Advisory and Coordinating Committee", Circulation, vol. 106, no. 3, pp. 388-391, 2002.

[14] ACSM, "American College of Sports Medicine Position Stand. Progression Models in Resistance Training for Healthy Adults", Med Sci Sports Exerc, vol. 41, no. 3, pp. 687-708, 2009.

[15] Mcbride Jeffrey M., Triplett-Mcbride Travis, Davie Allan,Newton Robert U., "A Comparison of Strength and Power Characteristics between Power Lifters, Olympic Lifters, and Sprinters", J Strength Cond Res, vol. 13, no. 1, pp. 58-66, 1999.

[16] William P. E. , "Complex Training: A Brief Review", J Sports Sci.Med., vol. 1, no.pp. 42-46, 2002.

[17] Hermassi S., Chelly M. S., Tabka Z., Shephard R. J.,Chamari K., "Effects of 8-Week in-Season Upper and Lower Limb Heavy Resistance Training on the Peak Power, Throwing Velocity, and Sprint Performance of Elite Male Handball Players", J Strength Cond Res, vol. 25, no. 9, pp. 2424-2433, 2011.

[18] Sayers S. P.,Gibson K., "A Comparison of High-Speed Power Training and Traditional Slow-Speed Resistance Training in Older Men and Women", J Strength Cond Res, vol. 24, no. 12, pp. 3369-3380, 2010.

[19] Robbins D. W., Young W. B., Behm D. G.,Payne W. R., "Effects of Agonist-Antagonist Complex Resistance Training on Upper Body Strength and Power Development", J Sports Sci, vol. 27, no. 14, pp. 1617-1625, 2009.

[20] Harries S. K., Lubans D. R.,Callister R., "Resistance Training to Improve Power and Sports Performance in
Adolescent Athletes: A Systematic Review and Meta-Analysis", J Sci Med Sport, vol. no. pp. 2012.

[21] Faul F., Erdfelder E., Buchner A.,Lang A. G., "Statistical Power Analyses Using G*Power 3.1: Tests for Correlation and Regression Analyses", Behav. Res. Methods., vol. 41, no. 4, pp. 1149-1160, 2009.

[22] Hagerman F. C., Walsh S. J., Staron R. S., Hikida R. S., Gilders R. M., Murray T. F., Toma K.,Ragg K. E., "Effects of High-Intensity Resistance Training on Untrained Older Men. I. Strength, Cardiovascular, and Metabolic Responses", J Gerontol A Biol Sci Med Sci, vol. 55, no. 7, pp. B336-346, 2000 .

[23] Lemura L. M., Von Duvillard S. P., Andreacci J., Klebez J. M., Chelland S. A.,Russo J., "Lipid and Lipoprotein Profiles, Cardiovascular Fitness, Body Composition, and Diet During and after Resistance, Aerobic and Combination Training in Young Women", Eur J Appl Physiol, vol. 82, no. 5-6, pp. 451-458, 2000

[24] Hazley L., Ingle L., Tsakirides C., Carroll S.,Nagi D., "Impact of a Short-Term, Moderate Intensity, Lower Volume Circuit Resistance Training Programme on Metabolic Risk Factors in Overweight/Obese Type 2 Diabetics", Res Sports Med, vol. 18, no. 4, pp. 251-262, 2010 .

[25] Banz W. J., Maher M. A., Thompson W. G., Bassett D. R., Moore W., Ashraf M., Keefer D. J.,Zemel M. B., "Effects of Resistance Versus Aerobic Training on Coronary Artery Disease Risk Factors", Exp Biol Med (Maywood), vol. 228, no. 4, pp. 434-440, 2003.

[26] Elliott K. J., Sale C.,Cable N. T., "Effects of Resistance Training and Detraining on Muscle Strength and Blood Lipid Profiles in Postmenopausal Women", Br J Sports Med, vol. 36 , no. 5 , pp. 340-344, 2002.

[27] Ghanbari-Niaki A., Saghebjoo M.,Hedayati M., "A Single Session of Circuit-Resistance Exercise Effects on Human Peripheral Blood Lymphocyte Abcal Expression and Plasma Hdl-C Level", Regul Pept, vol. 166, no. 1-3, pp. 42-47, 2011.

[28] Kokkinos P. F., Hurley B. F., Vaccaro P., Patterson J. C., Gardner L. B., Ostrove S. M.,Goldberg A. P., "Effects of Low-and High-Repetition Resistive Training on Lipoprotein - Lipid Profiles", Med Sci Sports Exerc, vol. 20, no. 1, pp. 50-54, 1988.

[29] Vincent K. R., Braith R. W., Bottiglieri T., Vincent H. K.,Lowenthal D. T., "Homocysteine and Lipoprotein Levels Following Resistance Training in Older Adults", Prev Cardiol, vol. 6, no. 4, pp. 197-203, 2003.

[30] Costa R. R., Lima Alberton C., Tagliari M.,Martins Kruel L. F., "Effects of Resistance Training on the Lipid Profile in Obese Women", J Sports Med Phys Fitness, vol. 51, no. 1, pp. 169-177, 2011.

[31] Fahlman M. M., Boardley D., Lambert C. P.,Flynn M. G., "Effects of Endurance Training and Resistance Training on Plasma Lipoprotein Profiles in Elderly Women", J Gerontol A Biol Sci Med Sci, vol. 57, no. 2, pp. B54-60, 2002.

[32] Prabhakaran B., Dowling E. A., Branch J. D., Swain D. P.,Leutholtz B. C., "Effect of 14 Weeks of Resistance Training on Lipid Profile and Body Fat Percentage in Premenopausal Women", Br J Sports Med, vol. 33, no. 3, pp. 
190-195, 1999.

[33] Tambalis K., Panagiotakos D. B., Kavouras S. A.,Sidossis L. S., "Responses of Blood Lipids to Aerobic, Resistance, and Combined Aerobic with Resistance Exercise Training: A Systematic Review of Current Evidence", Angiology, vol. 60, no. 5, pp. 614-632, 2009.
[34] Vasankari T., Lehtonen-Veromaa M., Mottonen T., Ahotupa M., Irjala K., Heinonen O., Leino A.,Viikari J., "Reduced Mildly Oxidized Ldl in Young Female Athletes", Atherosclerosis, vol. 151, no. 2, pp. 399-405, 2000.

[35] Kujala U. M., Ahotupa M., Vasankari T., Kaprio J.,Tikkanen M. J., "Low Ldl Oxidation in Veteran Endurance Athletes", Scand J Med Sci Sports, vol. 6, no. 5, pp. 303-308, 1996. 